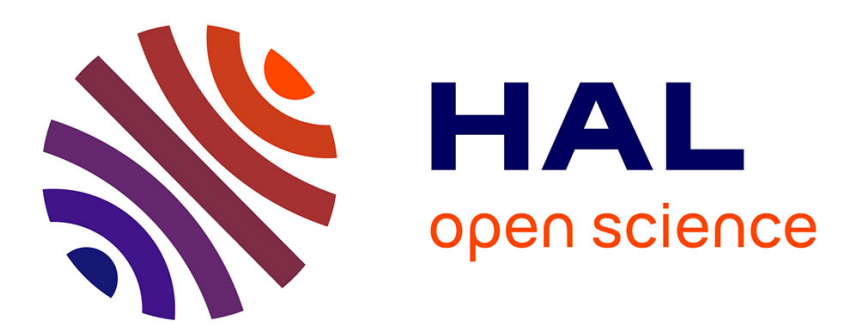

\title{
Anodic oxidation of chiral sulfinylamines: a new route to highly diastereoselective a-alkylation of piperidine
}

Serge Turcaud, Thierry Martens, Emma Sierecki, Joelle Pérard-Viret, Jacques Royer

\section{- To cite this version:}

Serge Turcaud, Thierry Martens, Emma Sierecki, Joelle Pérard-Viret, Jacques Royer. Anodic oxidation of chiral sulfinylamines: a new route to highly diastereoselective a-alkylation of piperidine. Tetrahedron Letters, 2005, 46 (31), pp.5131-5134. 10.1016/j.tetlet.2005.05.123 . hal-03385953

\section{HAL Id: hal-03385953 https://hal.science/hal-03385953}

Submitted on 19 Oct 2021

HAL is a multi-disciplinary open access archive for the deposit and dissemination of scientific research documents, whether they are published or not. The documents may come from teaching and research institutions in France or abroad, or from public or private research centers.
L'archive ouverte pluridisciplinaire HAL, est destinée au dépôt et à la diffusion de documents scientifiques de niveau recherche, publiés ou non, émanant des établissements d'enseignement et de recherche français ou étrangers, des laboratoires publics ou privés. 


\title{
Anodic oxidation of chiral sulfinylamines: a new route to highly diastereoselective $\alpha$-alkylation of piperidine
}

\author{
Serge Turcaud, Thierry Martens, Emma Sierecki, Joëlle Pérard-Viret and Jacques Royer* \\ Synthèse et structure de molécules d'intérêt pharmacologique, UMR 8638 CNRS-University Paris 5, Faculty of Pharmacy, \\ 4 avenue de l'Observatoire, 75270 Paris cedex 6, France
}

\begin{abstract}
The anodic oxidation of some chiral non-racemic $N$-arylsulfinyl piperidines was investigated and for the first time $\alpha$ methoxylated sulfinyl piperidines were obtained. The so-formed compounds are equivalent of chiral $N$-sulfinyliminiums and used as new intermediates for the preparation of chiral $\alpha$-substituted piperidine derivatives in good yield and diastereoselectivity.
\end{abstract}

Stereoselective substitution at the $\alpha$ position of secondary amines offers opportunities for convenient and efficient syntheses of nitrogen containing derivatives. Nevertheless, this sequence remains challenging and, despite several attempts, very few reactions permitting this substitution have been described so far.

Both anionic and cationic routes were reported. Deprotonation $\alpha$ to the nitrogen was investigated ${ }^{1}$ with some success and asymmetric versions ${ }^{1-3}$ exist whilst confined to the alkylation of allylamines ${ }^{2 b}$ and pyrrolidines. ${ }^{2 a, 3}$ The cationic pathway has been extensively studied (Scheme 1). A secondary amine $\mathbf{1}$ is transformed to $\alpha$ methoxy derivative $\mathbf{3}(Z=C O O R)$ via carbamate $\mathbf{2}$ $(\mathrm{Z}=\mathrm{COOR})$ using the Shono's anodic oxidation. ${ }^{4}$ The methoxy compound 3 reacts with a nucleophile in the presence of a Lewis acid to give the substituted derivative 5 via acyliminium $4 .{ }^{5}$ This anodic oxidation-amidoalkylation sequence is a very powerful method allowing the introduction of various nucleophiles. ${ }^{6}$ Moreover this process is very easy to perform and does not need any special technical knowledge. ${ }^{7}$ Surprisingly, few asymmetric developments of this efficient methodology appeared in the literature. Use of chiral carbamates led to disappointing diastereoselectivities ${ }^{8}$ (except if a chiral center is already present on the starting amine 1). ${ }^{9} \mathrm{~A}$ recent example using a chiral Lewis acid and providing an

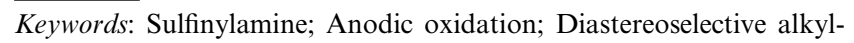
ation; Pelletierine.

* Corresponding author. Tel.: +33 153739749; fax: +33 143291403; e-mail: jacques.royer@univ-paris5.fr

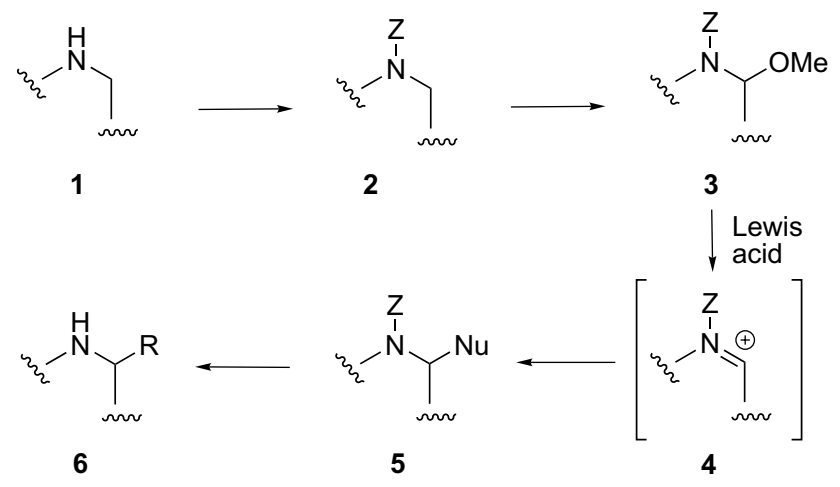

Scheme 1.

encouraging $56 \%$ ee was also reported. ${ }^{10}$ It thus appeared that improvement of the diastereoselectivity would call for the choice of another type of chiral activating $\mathrm{Z}$ group besides carbamates.

Several reports from the literature showed that diastereoselectivities for addition of nucleophiles to chiral sulfinylimines are consistently good to excellent. ${ }^{11}$ Thus, we planned to study the use of sulfoxide as chiral auxiliary in the oxidation/alkylation sequence described in Scheme $1(\mathrm{Z}=\mathrm{S} *(\mathrm{O}) \mathrm{R})$.

To the best of our knowledge there is no report in the literature neither concerning the generation of $\mathrm{N}, \mathrm{O}$-acetal equivalent of $N$-sulfinyliminium by direct oxidation of sulfinylamine, nor their use in the alkylation step. 


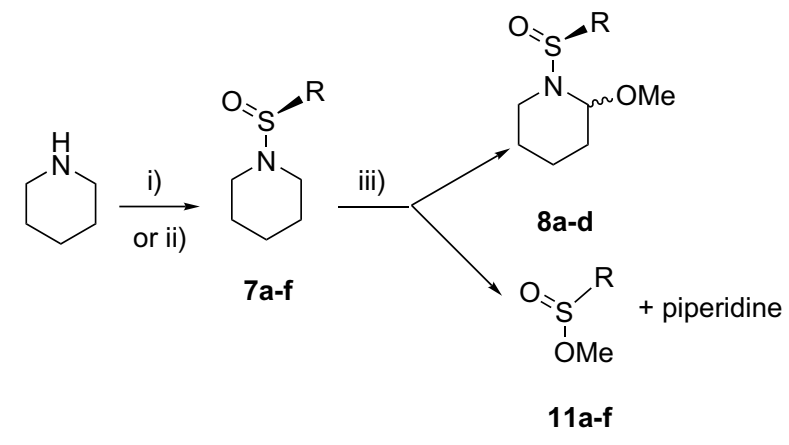

Scheme 2. Reagents and conditions: (i) $\mathrm{MeMgBr}, \mathrm{THF}, 0^{\circ} \mathrm{C}$, then menthyl arylsulfinate, 1 equiv; (ii) for $7 \mathbf{f}$ : $\mathrm{BuLi}, \mathrm{THF},-78{ }^{\circ} \mathrm{C}$, then $t$-BuSS$(\mathrm{O}) t$-Bu; (iii) anodic oxidation. ${ }^{18}$

Only one example of $N$-sulfinyliminium was described (as the expected intermediate in the Pictet-Spengler reaction of $(R)-N$ - $p$-toluenesulfinyltryptamine). ${ }^{12}$

We now report on the first successful electrochemical oxidation of chiral $N$-sulfinylamine to $\alpha$-alkoxy- $N$-sulfinylamine and the diastereoselective addition of a nucleophile onto this potential sulfinyliminium. In this preliminary study, we investigated some chiral sulfoxide groups as $N$-activating group (Z, Scheme 1) of the piperidine ring chosen as a model substrate (Scheme 2). The sequence was applied to the asymmetric synthesis of pelletierine (10).

$N$-Sulfinyl piperidines 7 were prepared $^{13}$ according to the literature ${ }^{14}$ with some modifications. The enantioenriched $N$-arylsulfinyl piperidines $7 \mathbf{a}-\mathbf{d}$ were obtained in high yields and ee (Table 1) by addition of piperidine magnesium bromide to the diastereomerically pure menthyl sulfinates. ${ }^{15}$ Compound $7 \mathrm{e}$ was prepared in only $30 \%$ ee from unseparated mesityl menthyl sulfinate diastereoisomers and $\mathbf{7 f}$ was prepared in racemic form from $t$ - $\mathrm{BuSS}(\mathrm{O}) t-\mathrm{Bu}^{16}$ and piperidine lithium. ${ }^{17}$

The oxidation step was particularly challenging and hypothetic since both nitrogen and sulfur atoms can be oxidized. Indeed, the anodic oxidation of sulfinylamines was reported by D'Oca et al. ${ }^{19}$ to give sulfur oxidation or $\mathrm{N}-\mathrm{S}$ bond cleavage. ${ }^{20}$ However, fragmentary data from the literature suggested that the regioselective nitrogen oxidation is possible. ${ }^{21}$

We reasoned that this electrochemical procedure should be quite sensitive to the reaction conditions. The anodic

Table 1. Preparation and anodic oxidation of $N$-sulfinyl piperidines 7

\begin{tabular}{|c|c|c|c|c|c|c|}
\hline & \multirow[t]{2}{*}{$\mathrm{R}$} & \multicolumn{2}{|c|}{7} & \multicolumn{2}{|l|}{8} & \multirow[t]{2}{*}{11} \\
\hline & & Yield (\%) & ee $(\%)$ & Yield $(\%)$ & $\mathrm{dr}$ & \\
\hline $\mathbf{a}$ & $p$-Tol & 84 & 98 & 69 & $75 / 25$ & 13 \\
\hline b & $o$-Tol & 82 & 94 & 48 & $82 / 18$ & 26 \\
\hline c & $\mathrm{Ph}$ & 88 & 98 & 67 & $73 / 27$ & 15 \\
\hline d & $o-\mathrm{CF}_{3}-\mathrm{C}_{6} \mathrm{H}_{4}$ & 87 & 99 & 71 & $90 / 10$ & 17 \\
\hline e & Mesityl & 73 & 30 & 0 & - & 66 \\
\hline f & $t-\mathrm{Bu}$ & 61 & 0 & 0 & - & - \\
\hline
\end{tabular}

oxidation is known to generate protons, which can be a serious drawback for the integrity of $\mathrm{N}-\mathrm{S}$ bond. ${ }^{11 \mathrm{a}}$ The first very simple idea was to perform the anodic oxidation in the presence of added base. Furthermore, it can help in the kinetic of deprotonation of the expectedly formed nitrogen centered cation-radical. After some trials, it was found that anodic oxidation, ${ }^{18}$ at constant current with graphite plate electrodes, of sulfinylamine 7a ( $\mathrm{R}=p$-tolyl) in $\mathrm{MeOH}$ and in the presence of $\mathrm{KHCO}_{3}$ occurred cleanly to furnish the desired $\alpha$ methoxylated derivative $\mathbf{8 a}$ in a good $69 \%$ yield as a mixture $(75: 25)$ of two diastereoisomers. The enantiomeric purity of each diastereoisomer was checked by chiral HPLC and no racemization was observed. The formation of methylsulfinate 11a corresponding to the $\mathrm{N}-\mathrm{S}$ bond cleavage reported by D'Oca et al. ${ }^{19}$ (Scheme 2) could not be completely avoided. Under more basic conditions, the formation of 11a was minimized and 8a was formed in a nice $77 \%$ yield but each diastereoisomer of $\mathbf{8 a}$ was proved to be only $80 \%$ ee. This partial racemization under these specific conditions is not clearly understood.

As it can be seen in Table 1, compounds $7 \mathbf{a}-\mathbf{d}$ gave the expected $\alpha$-methoxylated sulfinylamines $\mathbf{8 a}-\mathbf{d}^{13}$ in acceptable to good yields. The $\mathrm{N}-\mathrm{S}$ bond cleavage is still present in a small amount (about 15\%) in all cases regardless of the structure. It is noteworthy that compound 11 were found to be racemic products.

In contrast to the oxidation of $7 \mathbf{a}-\mathbf{d}, N$-sulfinyl piperidines 7e $(\mathrm{R}=$ mesityl) and $7 \mathbf{f}(\mathrm{R}=t-\mathrm{Bu})$ containing bulky groups led exclusively to cleavage products under several experimental conditions. This can be linked to their lower oxidation potential $(\mathrm{Ep}=1.3$ and $1.5 \mathrm{~V}$ sce for, respectively, 7f and 7e compared to 1.7-1.9 V sce for $7 \mathbf{a}-\mathbf{d})$.

The possibility to regenerate the sulfinyliminium from the $\alpha$-methoxylated product $\mathbf{8}$ and the diastereoselectivity of the addition of a nucleophile were then investigated. When 8a was treated with trimethylsilyloxypropene at $-78^{\circ} \mathrm{C}$ in the presence of 0.4 equiv of TMSOTf, the $N$-sulfinyl amino ketone 9a was obtained in a fair $64 \%$ yield and a nice 90:10 diastereoisomeric ratio (Scheme 3 ). This ratio was determined by HPLC and NMR analyses on the crude reaction mixture. The absence of racemization at sulfur atom was once again checked by chiral HPLC on each diastereoisomer. The methoxylated derivatives $8 \mathbf{b}-\mathbf{d}$ proceeded as well with de ranging from $64 \%$ to $84 \%$ (Table 2 ). A by-product was systematically observed and identified as the $S$-alkylated derivative $12 .^{22}$ In each case the major isomer of $9^{13}$ is obtained pure after simple flash chromatography.

Brief treatment $(10 \mathrm{~min})$ with 0.5 equiv of a $0.5 \mathrm{M}$ aqueous $\mathrm{H}_{2} \mathrm{SO}_{4}$ solution in $\mathrm{MeOH}$ gave quantitatively the $(S)$-enantiomer of pelletierine sulfate $(\mathbf{1 0}):\left([\alpha]_{\mathrm{D}}+28.9\right.$ $\left.\left(c 0.9, \mathrm{H}_{2} \mathrm{O}\right)\right)^{23}$ without epimerization. This very simple cleavage of the $N$-sulfoxide bond contrasts with the tedious cleavage of carbamates. The alkylation of $\alpha$-methoxylated sulfinylamines $\mathbf{8 a}-\mathbf{d}$ possessing a $(S)$-sulfoxide 

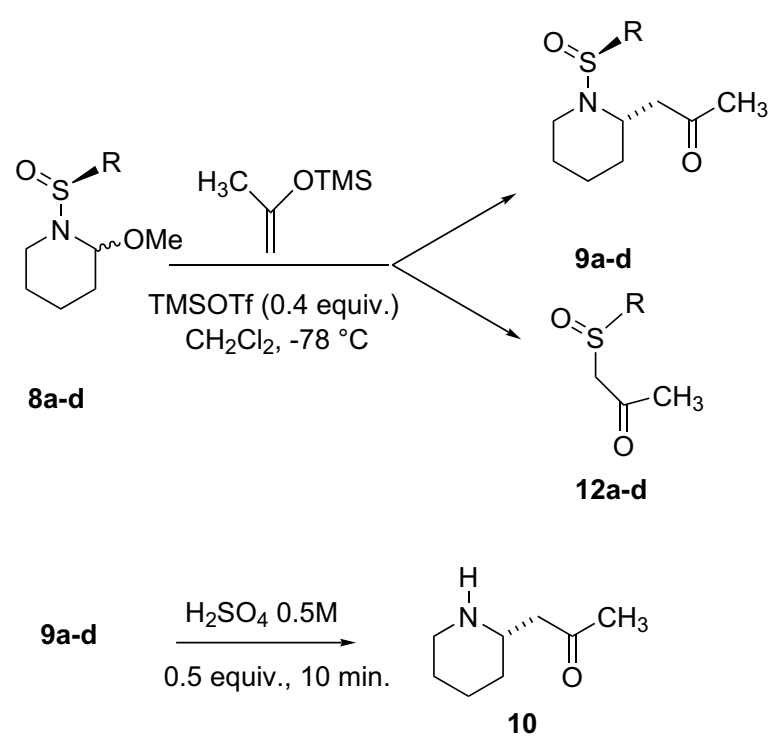

Scheme 3.

Table 2. Diastereoselective alkylation of methoxylated $N$-sulfinyl piperidines $\mathbf{8}$

\begin{tabular}{lllll}
\hline & $\mathrm{R}$ & \multicolumn{2}{c}{$\mathbf{9}$} & $\mathbf{9}$ \\
\cline { 3 - 4 } & & Isolated yield $(\%)$ & $\mathrm{de}$ & \\
\hline a & $p$-Tol & 64 & 80 & $92: 8$ \\
b & $o$-Tol & 55 & 84 & $83: 17$ \\
c & $\mathrm{Ph}$ & 60 & 80 & $82: 18$ \\
d & $o-\mathrm{CF}_{3}-\mathrm{C}_{6} \mathrm{H}_{4}$ & 62 & 64 & $82: 18$ \\
\hline
\end{tabular}

moiety gave $\mathbf{1 0}$ with the $(S)$ configuration. The same configuration was reported upon alkylation of $(S)$ - $p$ toluenesulfinyl imine with several nucleophiles, ${ }^{11 \mathrm{c}}$ suggesting analogue diastereocontrol with chiral sulfinyliminium.

In conclusion, we showed for the first time that $N$-sulfinylamines can be transformed to the corresponding $\alpha$ methoxy $N$-sulfinylamines through anodic oxidation. This allowed us to prepare chiral non-racemic equivalent of sulfinyliminium on $0.5 \mathrm{~g}$ scale. The so-formed $\alpha$-methoxylated $N$-sulfinylamines can react as potential sulfinyliminium allowing highly diastereoselective alkylation. The $\mathrm{R}$ group beared at the sulfoxide is important to the success of the anodic oxidation, while several substituents allow the alkylation reaction to occur in good yield and diastereoselectivity.

The overall sequence is a short (four steps) procedure to diastereomerically $\alpha$-alkylate secondary amines. The generalization of this procedure to other amines and nucleophiles is under investigation.

\section{Acknowledgements}

The authors thank the CNRS and the French Ministry of Education and Research for funding.

\section{References and notes}

1. (a) Gawley, R. E.; Rein, C. In Comprehensive Organic Synthesis; Trost, B. M., Fleming, I., Eds.; Pergamon Press: Oxford, 1991; Vol. 3, pp 65-83; (b) Beak, P.; Basu, A.; Gallagher, D. J.; Park, Y. S.; Thayumanavan, S. Acc. Chem. Res. 1996, 29, 552-560.

2. (a) Beak, P.; Kerrick, S. T.; Wu, S.; Chu, J. J. Am. Chem. Soc. 1994, 116, 3231-3239; (b) $N$-allylamines are easily deprotonated giving mainly $\gamma$-subtituted products, see for example: Whisler, M.; Beak, P. J. Org. Chem. 2002, 68, 1207-1215.

3. (a) Beak, P.; Lee, W. K. J. Org. Chem. 1993, 58, 1109 1117; (b) Bailey, W. F.; Beak, P.; Kerrick, S. T.; Ma, S.; Wiberg, K. B. J. Am. Chem. Soc. 2002, 124, 1889-1896.

4. (a) Shono, T.; Matsumura, Y.; Tsubata, K. J. Am. Chem. Soc. 1981, 103, 1172-1176; (b) Shono, T. Tetrahedron 1984, 40, 811-850; (c) Shono, T. In Topics in Current Chemistry; Streckham, E., Ed.; Springer: Berlin, 1988; Vol. 148, p 131.

5. A variant was proposed allowing the direct substitution without isolation of methoxy derivative, for recent papers see: (a) Suga, S.; Nishida, T.; Yamada, D.; Nagaki, A.; Yoshida, J. J. Am. Chem. Soc. 2004, 126, 14338-14339; (b) Suga, S.; Susuki, S.; Yoshida, J. J. Am. Chem. Soc. 2002, 124, 30-31.

6. Overman, L. E.; Ricca, D. J. In Comprehensive Organic Synthesis; Trost, B. M., Flemming, I., Heathcock, C. H., Eds.; Pergamon: Oxford, 1991; Vol. 2, p 1007.

7. Moeller, K. D. Tetrahedron 2000, 56, 9527-9554.

8. (a) D'Oca, M. G.; Pilli, R. A.; Vencato, I. Tetrahedron Lett. 2000, 41, 9709-9712; (b) Gawley, R. E.; Barolli, G.; Madan, S.; Saverin, M.; O'Connor, S. Tetrahedron Lett. 2004, 45, 1759-1761.

9. For more recent examples see: (a) Aggarwal, V. K.; Astle, C. J.; Rogers-Evans, M. Org. Lett. 2004, 6, 1469-1471; (b) Hanessian, S.; Claridge, S.; Johnstone, S. J. Org. Chem. 2002, 67, 4261-4274; (c) Ma, D.; Yang, J. J. Am. Chem. Soc. 2001, 123, 9706-9707; (d) Halab, L.; Belec, L.; Lubell, W. D. Tetrahedron 2001, 57, 6439-6446.

10. Braun, M.; Kotter, W. Angew. Chem., Int. Ed. 2004, 43, 514-517.

11. For reviews see: (a) Davis, F. A.; Zhou, P.; Chen, B.-C. Chem. Soc. Rev. 1998, 27, 13-18; (b) Ellman, J. A.; Owens, T. D.; Tang, T. P. Acc. Chem. Res. 2002, 35, 984-995; (c) Zhou, P.; Chen, B.-C.; Davis, F. A. Tetrahedron 2004, 60, 8003-8030.

12. Gremmen, C.; Wanner, M. J.; Koomen, G.-J. Tetrahedron Lett. 2001, 42, 8885-8888.

13. The structures of all new compounds are supported by ${ }^{1} \mathrm{H}$, ${ }^{13} \mathrm{C}$ NMR spectra and HRMS data.

Compound 7a: white solid; mp: $66^{\circ} \mathrm{C} ;[\alpha]_{\mathrm{D}}^{22}+110(c 1.4$, $\mathrm{MeOH}) ;{ }^{1} \mathrm{H}$ NMR $\left(300 \mathrm{MHz}, \mathrm{CDCl}_{3}\right) \delta(\mathrm{ppm}): 7.48(\mathrm{~d}$, $J=8.1 \mathrm{~Hz}, 2 \mathrm{H}) ; 7.24(\mathrm{~d}, J=8.1 \mathrm{~Hz}, 2 \mathrm{H}) ; 3.01(\mathrm{~m}, 2 \mathrm{H})$; $2.90(\mathrm{~m}, 2 \mathrm{H}) ; 2.35(\mathrm{~s}, 3 \mathrm{H}) ; 1.51(\mathrm{~m}, 6 \mathrm{H}) .{ }^{13} \mathrm{C} \mathrm{NMR}$ $\left(75 \mathrm{MHz}, \mathrm{CDCl}_{3}\right) \delta(\mathrm{ppm}): 140.9 ; 140.2 ; 129.4 ; 126.1 ; 46.8$; 26.1; 23.9; 21.2. IR (Nujol): 2922, 2852, 1598, 1457, 1377, $1241 \mathrm{~cm}^{-1}$. HRMS: $\mathrm{m} / \mathrm{z}$ calcd for $\mathrm{C}_{12} \mathrm{H}_{17} \mathrm{NOSNa}$ (M+Na): 246.0929. Found: 246.0917.

Compound 8a: ${ }^{1} \mathrm{H}$ NMR (300 $\left.\mathrm{MHz}, \mathrm{CDCl}_{3}\right) \delta(\mathrm{ppm}): 7.49$ (m, 2H); 7.25 (m, 2H); 4.70 (br s, $1 \mathrm{H}$, major); 4.60 (br s, $1 \mathrm{H}$, minor); 3.38 (s, 3H, major); 3.33 (s, 3H, minor); $2.94(\mathrm{~m}$, $1 \mathrm{H}) ; 2.76(\mathrm{~m}, 1 \mathrm{H}) ; 2.37(\mathrm{~s}, 3 \mathrm{H}) ; 1.90(\mathrm{~m}, 1 \mathrm{H}) ; 1.71(\mathrm{~m}, 2 \mathrm{H})$, $1.49(\mathrm{~m}, 2 \mathrm{H}) ; 1.21(\mathrm{~m}, 1 \mathrm{H}) .{ }^{13} \mathrm{C} \mathrm{NMR}\left(75 \mathrm{MHz}, \mathrm{CDCl}_{3}\right) \delta$ (ppm): 141.1; 129.6 (minor)/129.4 (major); 126.2 (major)/ 126.1 (minor); 89.2 (major)/88.9 (minor); 55.5 (major)/55.2 (minor); 40.4; 37.7; 31.7 (major)/31.2 (minor); 26.4 (minor)/ 26.3 (major); 21.3; 18.3. IR (neat): 2941, 2827, 1594, 1443, 1091. HRMS: $\mathrm{m} / z$ calcd for $\mathrm{C}_{13} \mathrm{H}_{20} \mathrm{NSO}_{2} \mathrm{Na}: 276.1034$. 
Found: 276.1040. Compound 9a: white solid; mp: $50{ }^{\circ} \mathrm{C}$; $[\alpha]_{\mathrm{D}}^{22}+99(c 1.08, \mathrm{MeOH}) ;{ }^{1} \mathrm{H}$ NMR $\left(300 \mathrm{MHz}, \mathrm{CDCl}_{3}\right) \delta$ (ppm): 7.49 (d, $J=8.1 \mathrm{~Hz}, 2 \mathrm{H}) ; 7.28(\mathrm{~d}, J=8.1 \mathrm{~Hz}, 2 \mathrm{H})$; $4.13(\mathrm{~m}, 1 \mathrm{H}) ; 3.10(\mathrm{~m}, 2 \mathrm{H}) ; 2.86(\mathrm{~m}, 2 \mathrm{H}) ; 2.35(\mathrm{~s}, 3 \mathrm{H}) ; 2.40$ $(\mathrm{s}, 3 \mathrm{H}) ; 2.15(\mathrm{~s}, 3 \mathrm{H}) ; 1.81(\mathrm{~m}, 1 \mathrm{H}) ; 1.60(\mathrm{~m}, 4 \mathrm{H}) ; 1.40(\mathrm{~m}$, 1H). ${ }^{13} \mathrm{C}$ NMR $\left(75 \mathrm{MHz}, \mathrm{CDCl}_{3}\right) \delta(\mathrm{ppm}): 206.1 ; 141.0$; $140.2 ; 129.5 ; 126.2 ; 54.0 ; 45.4 ; 42.0 ; 31.0 ; 30.5 ; 26.0 ; 21.3$; 20.5. IR (Nujol): 2937, 2859, 1713, 1595, 1359, 1095, 1064. MS: $\quad m / z \quad 302 \quad(\mathrm{M}+\mathrm{Na})$. HRMS: $\mathrm{m} / \mathrm{z}$ calcd for $\mathrm{C}_{15} \mathrm{H}_{21} \mathrm{NO}_{2} \mathrm{SNa}(\mathrm{M}+\mathrm{Na}): 302.1191$. Found: 302.1195.

14. Garcia-Ruano, J.; Alonso, R.; Zarzuelo, M. M.; Noheda, P. Tetrahedron: Asymmetry 1995, 6, 1133-1142.

15. (a) Andersen, K. K. Tetrahedron Lett. 1962, 3, 93-95; (b) Klunder, J. M.; Sharpless, K. B. J. Org. Chem. 1987, 52, 2598-2602.

16. Netscher, T.; Prinzbach, H. Synthesis 1987, 683-688.

17. Cogan, D. A.; Liu, G.; Kim, K.; Backes, B. J.; Ellman, J. A. J. Am. Chem. Soc. 1998, 120, 8011-8019.

18. The electrolysis was conducted at $0^{\circ} \mathrm{C}$ in an undivided glass cell equipped with two graphite plate electrodes
$(35 \times 20 \mathrm{~mm})$ and at a constant current $(15 \mathrm{~mA})$, under nitrogen on a $0.05 \mathrm{M}$ methanolic solution of 7 containing $\mathrm{Et}_{4} \mathrm{NBF}_{4}$ ( 0.5 equiv) and $\mathrm{KHCO}_{3}$ (0.5 equiv). The course of the electrolysis was checked by HPLC, the terminal voltage was $4.5 \mathrm{~V}$.

19. D’Oca, M. G.; Russowsky, D.; Canto, K.; Gressler, T.; Gonçalves, R. S. Org. Lett. 2002, 4, 1763-1766.

20. N-S cleavage was also observed in $N$-sulfinyl anilines: Carreno, M. C.; Ribagorda, M. J. Org. Chem. 2000, 65, $1231-1234$

21. (a) Hartung, C.; Illgen, K.; Sieler, J.; Schneider, B.; Schulze, B. Helv. Chim. Acta 1999, 82, 685-695; (b) Taubert, K.; Sieler, J.; Hennig, L.; Findeisen, M.; Schulze, B. Helv. Chim. Acta 2002, 85, 183-195; (c) Siegemund, A.; Hartung, C.; Baumann, S.; Schulze, B. Helv. Chim. Acta 2004, 87, 376-381.

22. The enantiomeric purity of $\mathbf{1 2}$ was not checked.

23. Reported values for the natural $(R)$ isomer: $[\alpha]_{\mathrm{D}}-29.5(c$ 1.09, $\mathrm{H}_{2} \mathrm{O}$ ): Gilman, R. E.; Marion, L. Bull. Soc. Chim. Fr. 1961, 1993-1995. 